\title{
THE EFFECT OF WORKING CAPITAL ON THE PROFITABILITY OF PALM OIL PLANTATION COMPANIES
}

\section{Tania Prafitri*)1, Dwi Rachmina**), and Tubagus Nur Ahmad Maulana*)}

*) School of Business, Bogor Agricultural University

Pajajaran Road, Bogor 16151

***) Department of Agribusiness, Faculty of Economics and Management, Bogor Agricultural University Kamper Road, Wing 4 Level 5, IPB Darmaga Campus, Bogor 16680

\begin{abstract}
Management decisions related to working capital are based on the management of short-term assets and liabilities, aiming to ensure that the company is able to maintain the operations and have sufficient cash flows to finance short-term debt maturities and operational costs, as well as to improve the profitability of the company. The objective of this study is to examine the effect of working capital management on company profitability. Working capital is considered to be an important issue in financial management and have an effect on liquidity as well as on the company profitability. In addition, optimized working capital management contributes greatly to the achievement of company objectives. The secondary data were taken from the annual reports of 6 oil palm plantation companies registered in the Indonesia Stock Exchange (IDX) during the year 2009-2015. Profitability as a dependent variable was measured by return on investment (ROI). Cash conversion cycle (CCC), current ratio (CR), financial debt ratio (FDR), and fixed financial asset ratio (FFAR) are independent variables. The analytical model used in this study was panel regression by using Fixed Effect Model. The results showed that there is a negative effect of working capital on profitability. Profitability will increase as cash cycle conversion cycle decreases. This is because companies with short cash conversion cycle are able to collect the cash needed for the company's day-to-day operations.
\end{abstract}

Keywords: working capital, cash conversion cycle, current ratio, debt ratio, fixed assets ratio. profitability

\begin{abstract}
ABSTRAK
Keputusan manajemen yang berkaitan dengan modal kerja didasari oleh cara pengelolaan antara aset dan kewajiban jangka pendek, hal ini bertujuan untuk memastikan bahwa perusahaan mampu untuk melanjutkan kegiatan operasional dan memiliki arus kas yang cukup untuk membiayai hutang jangka pendek yang jatuh tempo dan biaya kegiatan operasional, serta untuk meningkatkan profitabilitas perusahaan. Tujuan dari makalah ini adalah menganalisis pengaruh manajemen modal kerja terhadap profitabilitas perusahaan. Modal kerja dianggap sebagai masalah yang penting dalam manajemen keuangan dan memiliki efek pada likuiditas serta pada profitabilitas perusahaan. Selain itu, manajemen modal kerja yang optimal memberikan kontribusi yang besar dalam pencapaian tujuan perusahaan. Penulis menggunakan data sekunder yang bersumber dari laporan tahunan 6 perusahaan perkebunan kelapa sawit yang terdaftar di Bursa Efek Indonesia (BEI) selama tahun 2009-2015. Profitabilitas sebagai variabel dependen diukur dengan return on investment (ROI). Cash conversion cycle (CCC), current ratio (CR), financial debt ratio (FDR), dan fixed financial asset ratio (FFAR) merupakan variabel independen. Model analisis yang digunakan adalah model regresi panel menggunakan Fixed Effect Model. Hasil penelitian menunjukkan bahwa ada pengaruh negatif dari modal kerja terhadap profitabilitas. Profitabilitas akan bertambah saat waktu siklus konversi kas berkurang. Hal ini dikarenakan perusahaan yang memiliki waktu siklus konversi kas yang pendek mampu mengumpulkan kas yang diperlukan untuk operasional seharihari perusahaan.
\end{abstract}

Kata kunci: modal kerja, siklus konversi kas, rasio lancar, rasio hutang, rasio aktiva tetap profitabilitas

\footnotetext{
${ }^{1}$ Corresponding author:

Email: taniaprafitri.tp@gmail.com
} 


\section{INTRODUCTION}

The working capital management is an essential part of each economic unit and is categorized as the most important function in company management. Each organization, both profit-oriented and non-profit, and regardless of the size and nature of the business, requires a sufficient amount of working capital to conduct business operations (Mukhopadhyay, 2004). Therefore, it is important to acknowledge the way working capital management policy affects the performance of the company. Initially, the primary objective of working capital management was to maintain sufficient cash to meet due claims from creditors. However, the concept of working capital management has changed and currently includes the management of all current assets; including cash, securities, accounts receivable, inventories and current liabilities (Raheman et al. 2011).

A common measurement of working capital management is the cash conversion cycle; i.e. the time span required between expenditures for raw material purchases and receipt of payments for finished goods selling. The longer the time, the bigger the investment needed in working capital. In addition, reduced cash conversion cycle will improve the profitability of the company.

One of the profit sources in a company is derived from sales revenue of production. The production process of oil palm plantation companies is different from other types of companies. For instance, in manufacturing companies, the company management will add raw materials and working hours as an effort to improve the production which later will increase the company profit. In the plantation company, the production of the company cannot be changed by increasing the raw material or extending the working hours. This is because some plantation products, such as fruits, cannot be reproduced by adding working hours or fruit seedlings. The production of plantation companies like fruits depends on the production and harvesting time; which makes the plantation company different from other industries. Oil palm plantation companies are expected to contribute in the economy, considering that oil palm plantation is one of the leading plantation commodities in Indonesia.
The presence of palm oil as a leading commodity enables it to become a highly promising business opportunity in future time. An increase in global competition along with a continuous increase in the number of oil palm plantation companies makes oil palm plantation companies in Indonesia become more effective and efficient in their management in order to survive in the midst of business competition.

The rapid growth of oil palm is generally associated with the level of profitability of commodity companies which is relatively better. In addition, the government policy also encourages the expansion of the commodity area. According to Valentina (2014), the greater the level of profitability is, the better the company will be. The higher the level of company profitability is, the greater the level of prosperity given by the company to the shareholders will be. Thus, the greater prosperity level provided by the company will attract investors to place funds in the company and give a positive effect on stock prices in the market. Ultimately, it will raise the value of the company. The financial development of oil palm plantation companies listed on the ISE in 2009-2015 can be seen in Figure 1. Profit and net working capital become the indicators in the financial development of oil palm plantation companies.

It can be seen in Figure 1 that most companies experienced significant profit decline in 2013; particularly PT. Astra Agro Lestari Tbk (AALI) and PT. BW Plantation Tbk (BWPT) that had undergone a deficit. Nevertheless, the companies still gained a slight increase of $2.82 \%$ from Rp764.37 to Rp786.10 billion by September 2013 in the same one-year period. This is caused by the decreased selling price of CPO affecting the performance of the company. Moreover, the cost increases as the area expansion for the mature area of about 11 thousand hectares. The plantation industry experienced a decrease in profitability caused by the decline in the selling price of the products and the increase in production costs. The negative value of net working capital is due to the total amount of the company's debt which is greater than the amount of owned assets. Therefore, the company funding is likely to derive from debt.

As the prices of CPO and other palm oil plantation yields have been linked to the price of oil, investments in plantations have continued to increase. Investment in plantations requires substantial funds. The company 
management should consider the balance of the company's working capital usage. Yuliati (2013) explains that the structure of assets in financing working capital has a significant effect on profitability.

In general, it has been established that the company performance and profitability are highly dependent on the ways of working capital management. If a company is inefficient in managing working capital management, it will not only reduce profitability but also lead to financial crises. Inadequate and excessive working capital potentially harms a company. Excessive working capital can result in idle funds that should be utilized for profit while inadequate working capital can disrupt operations and reduce profitability (Chowdhury and Amin, 2007).

The effect of working capital management on profitability is also influenced by other factors i.e. current ratio, fixed financial asset ratio, and financial debt ratio. Through financial statements, the company's financial performance is examined by using liquidity ratios, activity, solvency, and profitability. In reference to the results of the analysis supported by statistical analysis, the management performance of accounts receivables, inventories, and accounts payable can be evaluated as components of working capital and their effects on the profitability of oil palm plantation companies. Managerial implications of the results of performance and statistical analysis can be identified as a recommendation to the management.
The purpose of this study is to analyze the profitability of oil palm plantation companies in 2009-2015, examine the effect of working capital management on the profitability of oil palm plantation companies in 2009-2015, and formulate working capital management strategies to be performed in oil palm plantation companies.

In order to exemplify the problem in this study, the scope of discussion was limited to the variables of working capital as measured by cash conversion cycle and its component (receivable turnover, debt turnover, and inventory turnover). In this study, profitability was not only influenced by working capital, but there were also other variables influencing the profitability of oil palm plantation companies.

Thus, the other variables included the current ratio, debt ratio, and rate of return on assets of the previous period. Meanwhile, the profitability was measured by return on investment. The financial report data utilized in this study were the balance sheet and income statement of the company for 7 years; i.e. from 2009 to 2015. During the period, the data were analyzed as they were adjusted to the availability of financial statements that can be accessed on Indonesia Stock Exchange site (www.idx.co.id). The objects of this study covered 6 companies listed on the Stock Exchange.

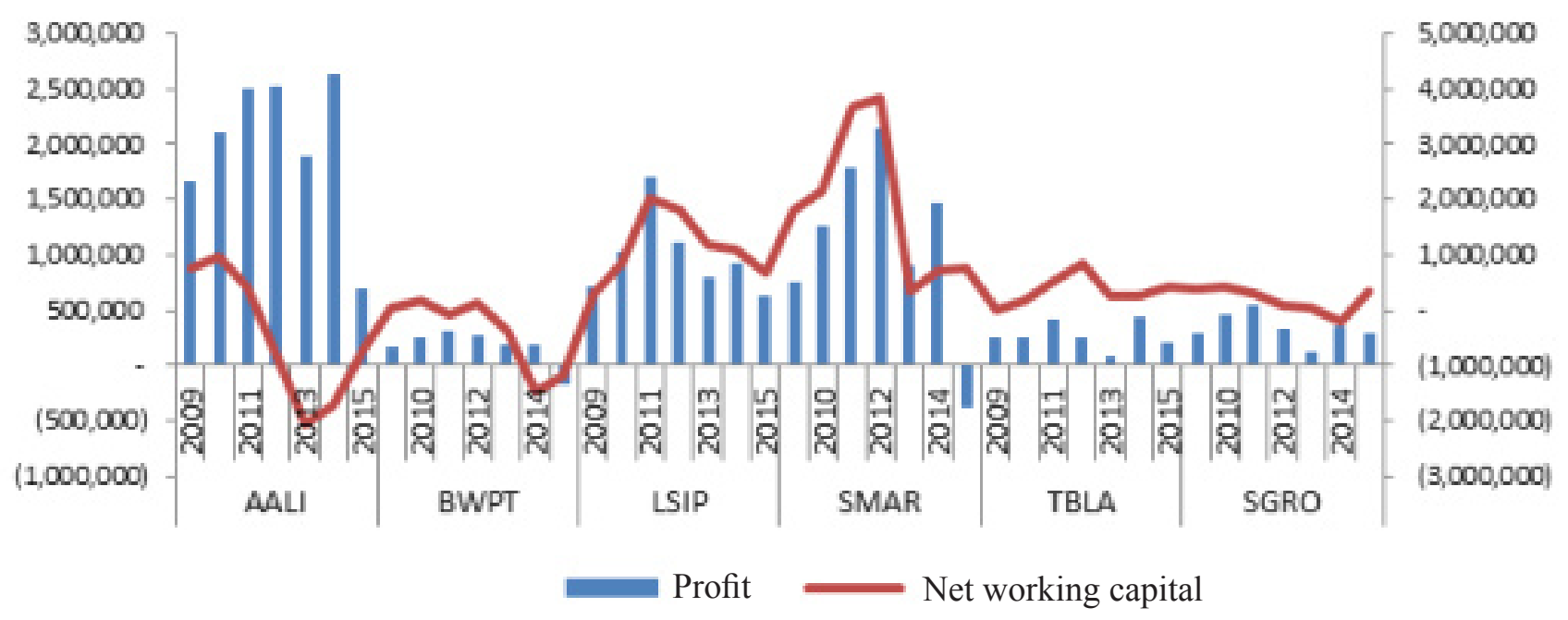

Source: Financial report of oil palm plantation companies at Indonesia Stock Exhange (ISE) in 2009-2015

Figure 1. Graph of financial development of oil palm plantation companies at Indonesia Stock Exhange (ISE) in 2009-2015 


\section{METHODS}

This study was conducted on 6 oil palm companies listed on ISE in 2009 to 2015. The type of data used in this study were the secondary data obtained from the annual financial statements that had been audited, and Annual Report of the company in 2009-2015. Within 7 years of research on 6 oil palm plantation companies (PT. Astra Agro Lestari Tbk (AALI); PT. BW Plantation Tbk (BWPT); PT. PP London Sumatera Indonesia Tbk (LSIP); PT. Sinar Mas Agro Resources and Technology Tbk (SMAR); PT. Tunas Baru Lampung Tbk (TBLA); PT. Sampoerna Agro Tbk (SGRO)) and 4 variables, the total samples gathered were 168 observations.

The panel regression was utilized as the method of the study requiring three different approaches; i.e. Pooled Least Square (PLS) model, Fixed Effect Model (FEM), and Random Effect Model (REM). The initial stages in the model processing result by using panel regression resulted in each approach.

\section{Chow Test:}

\section{H0 : Pooled Least Square}

H1 : Fixed Effect Model Redundant Fixed Effects Tests

Equation: Untitled

Test cross-section fixed effects

\begin{tabular}{lccc}
\hline Effects Test & Statistic & d.f. & Prob. \\
Cross-section F & 28.390930 & $(5,158)$ & 0.0000 \\
\hline
\end{tabular}

p-value of $<\alpha=5 \%$ rejects $\mathrm{H} 0$ meaning that the chosen model is FEM

\section{Hausman test:}

\section{H0 : Random Effect Model}

H1 : Fixed Effect Model Correlated Random Effects Hausman Test

Equation: Untitled

Test cross-section random effects

\begin{tabular}{lccc}
\hline Test Summary & $\begin{array}{c}\text { Chi-Sq. } \\
\text { Statistic }\end{array}$ & $\begin{array}{c}\text { Chi-Sq. } \\
\text { d.f. }\end{array}$ & Prob. \\
Cross-section random & 8.921156 & 4 & 0.0431 \\
\hline
\end{tabular}

Nilai-p $<\alpha=5 \%$, maka tolah H0 artinya model yang terpilih adalah FEM.

p-value of $<\alpha=5 \%$ rejects $\mathrm{H} 0$ meaning that the selected model is FEM
The result of model processing reveals that the analysis in this study should utilize the Fixed Effect Model (FEM) model. The result of the classical assumption testing in this study indicates that residuals do not spread normally. Also there are no heteroscedasticity and no multicolinearity.

In this research, mathematically, the effect of Cash Conversion Cycle (CCC), Current Ratio (CR), Financial Debt Ratio (FDR) and Fixed Financial Asset Ratio (FFAR) on company profitability ROI (Return on Investment) is described in the following formulation:

$$
\mathrm{ROI}_{\mathrm{it}}=\alpha+\beta_{1} \mathrm{CCC}_{\mathrm{it}}+\beta_{2} \mathrm{CR}_{\mathrm{it}}+\beta_{3} \mathrm{FDR}_{\mathrm{it}}+\beta_{4} \mathrm{FFAR}_{\mathrm{it}}+\varepsilon_{\mathrm{it}}
$$

Notes:

ROIit $=$ Return on Investment (percentage)

CCCit $=$ Cash Conversion Cycle (day)

CRit = Current Ratio (percentage)

FDRit $=$ Financial Debt Ratio (percentage)

FFARit $=$ Fixed Financial Asset Ratio $($ percentage $)$

$\mathrm{i} \quad=$ company rank $(\mathrm{i}=1,2, \ldots \ldots . ., 6$ companies $)$

$\mathrm{t}=$ series in 2009-2015

$\alpha \quad=$ intersep

$\beta 1-4=$ variable coefficient

eit $=$ error term

In which ROI is a measure of profitability (Earning after tax/ total assets); CCC is a measure of working capital (ACP + ITID-APP), ACP is the average billing period ([Accounts Receivable/Net Sales] x 365); ITID is the inventory turnover in days ([Inventories/ COGS] x 365); And APP is the average payment period ([Payable/purchase] $\mathrm{x} 365$ ); $\mathrm{CR}$ is the current ratio (current assets/current liabilities); FDR is the ratio of debt (total debt/total assets); FFAR is the ratio of fixed assets (total assets/total assets); E is an error term; I is the cross section of the company; And $t$ is the time series. This research analyzed the management of working capital on accounts receivable, inventory, and accounts payable, as well as its effect on profitability. Through financial statements, the company's financial performance was analyzed by using liquidity, activity, solvency, and profitability ratios. Based on the results of the analysis supported by statistical analysis, the management performance of accounts receivable, inventories, and accounts payable as components of working capital and their effect on the profitability of the company can be evaluated in this study on oil palm plantation companies. 
The management of elements of current assets covering cash, accounts receivables, and inventories are essential to be considered by the management company. The efficiency of cash management, accounts receivable and inventory will affect the ability to make a profit. A very large amount of cash to exceed current liabilities reflects the presence of a lot of idle funds that possibly minimize profitability.

The incorrect receivable policy will reduce the incoming cash flow and result in reduced funds for operations. Moreover, it ultimately affects the company's ability to make profit. The presence of excessive inventory investment compared to the needs will increase the burden, yet it reduces the profitability. In managing working capital, company management is encouraged to comprehend the cash conversion cycle in the company. The shorter the cash conversion cycle is, the better the condition of the company is. The profitability will increase as the cash conversion cycle decreases. Working capital policy is about how companies behave towards the fulfillment of working capital which can also affect the company profitability. The analytical framework of this study is exemplified in graphic in Figure 2.

The shorter the cash conversion cycle is, the better the company is. Profit will increase as cash cycle conversion cycle decreases. This is because companies that have short cash conversion cycle times are able to collect the cash needed for the day-to-day operations of the company, so there is no need to use external sources of funding which means no cost for debt funds and company profits will eventually increase (Brigham and Joel, 2011). Therefore, a hypothesis can be concluded as follows:

In reference to the literature review and the results of previous empirical researches, the hypotheses of this study were formulated as follow:

\section{Cash Conversion Cycle (CCC)}

The shorter the cash conversion cycle is, the better the effect for the company is. Profit will increase as cash cycle conversion cycle decreases. This is because companies that have short cash conversion cycle times are able to collect the cash needed for the day-to-day operations of the company. Consequently, there is no need to use external sources of funding which means no cost for debt funds, and further company profits will increase (Brigham and Joel, 2011). In reference to the explanation of the influence of both variables, a hypothesis can be drawn as follows:

Ha1: Cash Conversion Cycle has a negative effect on return on investment.

\section{Current Ratio (CR)}

The higher the current ratio is, the greater the company's ability to pay off its debts is. In the management of its working capital, particularly related to efficient working capital policy, the management of the company will be faced with a decision that leads to accounts off between liquidity and profitability. This is an important matter for business sustainability to gain attention.

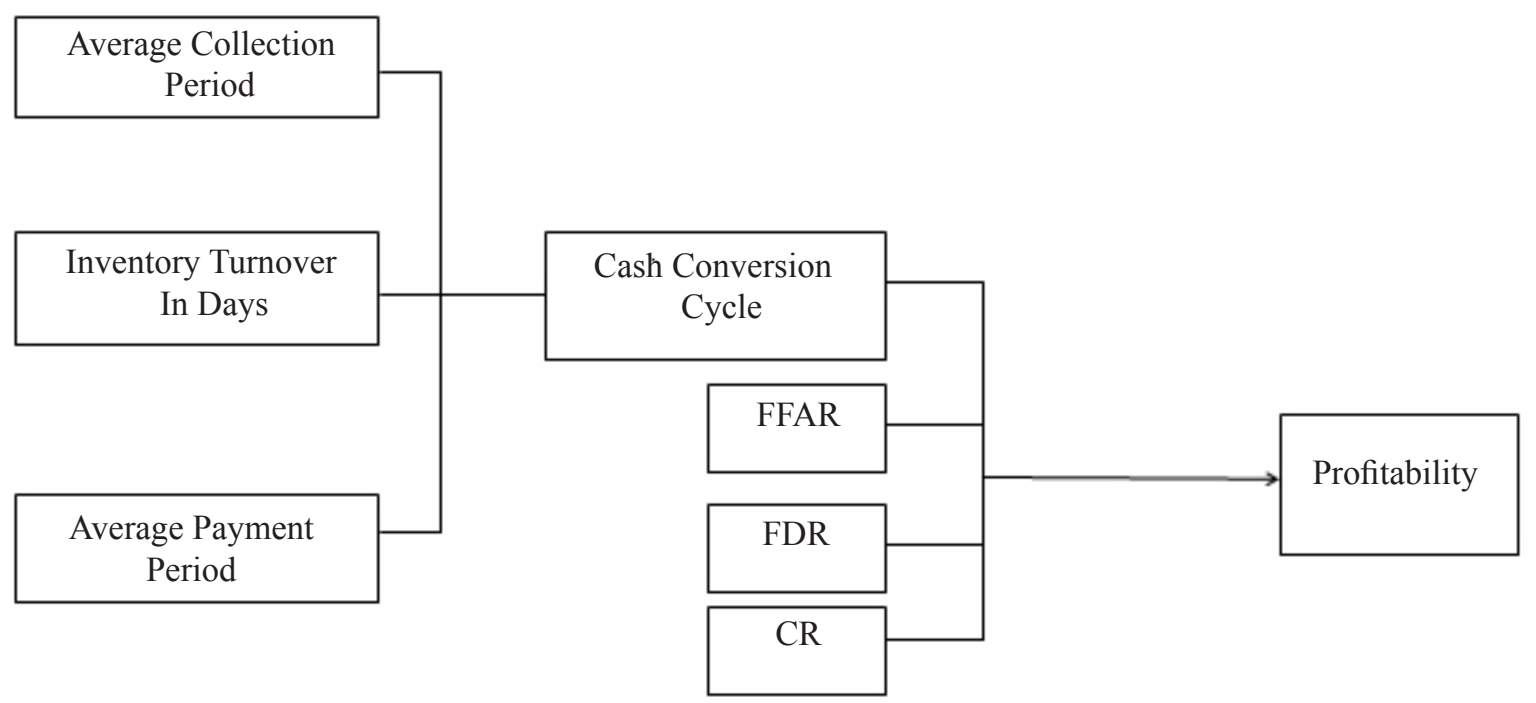

Figure 2. Research framework 
The decision to reduce the working capital as efficient as possible to maintain the liquidity level tends to decrease the company profitability. On contrary, the decision aiming to maximize the company profitability of companies tends to result in an unsatisfactory level of company liquidity. Based on the explanation, a hypothesis can be deduced as follow:

Ha2: Current Ratio has a negative effect on return on investment.

\section{Financial Debt Ratio (FDR)}

Financial debt of a company has a negative effect on profitability. FDR measures the extent to which company liabilities are utilized to fund purchases or investments or company assets. The greater the value of the ratio is, the greater the risk borne by the company is. Meanwhile, the smaller the value is, the better it gets as the amount of assets financed by debt becomes smaller.

Ha3: Financial Debt Ratio has a negative effect on return on investment.

\section{Fixed Financial Asset Ratio (FFAR)}

An increased component of fixed financial assets in the total assets of the company will increase the profitability. The higher the funding in the addition of assets; e.g. machinery, production equipment, etc. is, the more the increase of the generated production due to the increased equipment, increased sales of increased production quantities, and ultimately increased profit is.

Ha4: Fixed Financial Asset Ratio has a positive effect on return on investment.

\section{RESULTS}

\section{Profitability of Oil Palm Plantation Companies}

To answer the first objective by using descriptive statistics for research data variables, ROI was utilized as an indicator of profitability measurement with total observations of 168 . Processing by using panel regression required three model approaches; i.e. Pooled Least Square (PLS) model, Fixed Effect Model (FEM), and Random Effect Model (REM). The initial stages in the model processing results by using panel regression produced each approach. The result of model processing reveals that the analysis in this research further will use Fixed Effect Model (FEM) model. The result of the classical assumption testing of this study indicates that residuals do not spread normally. Also, there are no heteroscedasticity and no multicolinearity. The minimum value is the lowest value for each variable, and the maximum value is the highest value for each variable in the study; moreover, the means and deviation standards of each variable can be seen in Table 1 .

Profitability in this study was measured by return on investment (ROI) as the result of the division between profit after tax (EAT) and total assets. Table 1 highlights the average profitability of plantation companies at ISE of 2009-2015 i.e. 7\% with the lowest profitability of $-2 \%$ and the highest of $37 \%$. The sub-sector plantation on ISE has low ROI average (7\%). This is evident from the average of positive Cash Conversion Cycle (CCC) for 70 days, indicating that the company has longer age of accounts receivable than that of debt of its business. Plantation companies that have negative profitability values measured by ROI are PT Sinar Mas Agro Resources and Technology Tbk (SMAR). The weakening of the company profitability is due to the decrease in net sales of SMAR. As a result, it failed to realize the goals that were set in 2015. Meanwhile, the company that has the highest ROI is PT PP London Sumatera Indonesia Tbk (LSIP).

This is triggered by increased sales and direct impact on LSIP performance. LSIP produced 1.39 million tons of fresh fruit bunches in 2015. At the same time, LSIP CPO production indicated a growth from $7.4 \%$ to 475,708 tons. The increase in production is in line with the increase of fresh fruit bunches processed i.e. by 2 million tons and CPO extraction rate of $22.9 \%$ in 2015 . In reference to the production, the total of LSIP sales rose by $5.1 \%$ from 449,021 tons to 471,827 tons.

\section{Effect on Working Capital Management toward Profitability}

The primary purpose of the company operation is to earn profit. In its operations, the company needs funds to run the company, either to fund fixed assets or to fund its operations. Companies may use funding from both internal and external sources. There are a number of researches on the effect of working capital variables on profitability by using various approaches and resulting in various results. Nonetheless, in its essence, there is an influence between working capital variable on profitability. 
Table 1. Variable descriptive statistics in oil palm plantation companies at ISE in 2009-2015

\begin{tabular}{lccccc}
\hline \multicolumn{1}{c}{ Deskriptif } & CR (\%) & FDR (\%) & FFAR (\%) & ROI (\%) & LnCCC \\
\hline Mean & 1,438 & 0,434 & 0,666 & 0,074 & 4,108 \\
Median & 1,197 & 0,448 & 0,689 & 0,052 & 4,182 \\
Maximum & 4,833 & 0,724 & 0,867 & 0,367 & 6,185 \\
Minimum & 0,289 & 0,140 & 0,405 & $-0,027$ & 0,264 \\
Std. Dev. & 0,824 & 0,186 & 0,108 & 0,070 & 1,050 \\
\hline
\end{tabular}

Source: The financial statements of oil palm plantation companies at ISE in 2009-2015 (processed)

The efficiency of working capital utilization has a direct effect on the company profitability. It also adds one investment productivity to the company fixed assets. If adequate working capital is not available on time for the company, the sustainability of the company can be at risk. Subsequently, it is important to maintain sufficient supply of working capital for the healthy growth of a company (Jain, 2004).

The lack of empirical evidence on working capital management and its impact on company performance on the manufacturing sector in Pakistan is the primary motivation to examine the subject in detail. There are several studies in reference to working capital management in Pakistan; e.g. Raheman et al. (2010) analyzing the impact of working capital management on manufacturing sector performance in Pakistan.

Furthermore, Raheman et al. (2011) analyzed the impact of working capital management on company performance over nine sectors. Afza and Nazir (2008) investigated the factors determining working capital requirements as the samples of 204 companies in sixteen manufacturing sub-sectors in a period of 1998-2006. Their results highlight that working capital management plays an important role in increasing profits, risks and company value. It requires time to monitor and maintain the appropriate levels of its components e.g. cash, accounts receivables, accounts payable, and inventory.

Wang (2002) argues that the negative relationship between Cash Conversion Cycle, return on asset and return on equity is also sensitive to industrial factors. The results show that although there are differences in the financial system and structural characteristics of both countries, aggressive liquidity management improves company performance which later will also increase the values of Japanese and Taiwanese companies.
Nazir and Afza (2009) examine companies adopting aggressive working capital management policies which use current assets at a lower rate than their total assets. The study utilized profitability measures of "Tobin's q" and regression analysis in examining the relationship between the company's working capital management and its outcomes in Pakistan.

The results are signified to contradict the previous studies. This may be due to Pakistan's inconsistent and volatile economic conditions. Companies with more aggressive working capital policies are perceived to be unable to generate more profits. On the other hand, investors invest more values to companies with aggressive working capital approach, so the market value of the company is higher than its book value. In addition, investors believe that companies with less equity and less long-term loans will perform better than any other company.

\section{Estimation of the Effect of Working Capital on Profitability}

Processing by using panel regression requires three model approaches; i.e. Pooled Least Square (PLS) model, Fixed Effect Model (FEM), and Random Effect Model (REM). The initial stages in the model processing results by using panel regression produced each approach. The result of model processing reveals that the analysis in this research further used Fixed Effect Model (FEM) model. The results of the classical assumption testing in this study indicate that residuals do not spread normally. Also, there are no heteroscedasticity and multicolinearity. The results of the regression analysis on the model highlighting the effect of working capital on the profitability of oil palm plantation companies can be seen in Table 2 . 
Table 2. Analysis estimation of the effect of working capital on the profitability of oil palm plantation companies

\begin{tabular}{lcc}
\hline \multicolumn{1}{c}{ Variable } & Coefficient & Prob. \\
\hline Constanta & $0.105792^{* *}$ & 0.0241 \\
Ln Cash Conversion Cycle (Ln CCC) & $-0.019177^{* *}$ & 0.0000 \\
Current Ratio (CR) & $0.049175^{* *}$ & 0.0000 \\
Financial Debt Ratio (FDR) & $-0.193368^{* *}$ & 0.0000 \\
Financial Fixed Asset Ratio (FFAR) & $0.090249^{*}$ & 0.0884 \\
R-squared & 0.780380 & \\
Adjusted R-squared & 0.767870 & \\
\hline
\end{tabular}

Table 2 shows the LnCCC probability value by $0.0000<\alpha 10 \%$, indicating that LnCCC variable has a significant effect on ROI. Coefficient value by -0.019 also indicates that an increase in CCC by $1 \%$ will decrease ROI by $0.019 \%$ with an assumption of ceteris paribus. The shorter the cash conversion cycle is, the better the benefit for the company is. Profitability will increase as cash cycle conversion cycle decreases. This is because companies with short cash conversion cycle times are able to collect the cash needed for day-today operations of the company. Subsequently, there is no need to use external sources of funding i.e. no cost for borrowing funds and company profits will increase later (Brigham and Joel, 2011).

In this study, CCC coefficient has a negative and significant effect on return on investment. This is supported by the research conducted by Raheman et al. (2010) finding that cash conversion cycle has a negative relationship on the company profitability. Nonetheless, Chowdhury and Amin (2007) revealed a negative relationship between working capital and company performance.

The second hypothesis was to examine the effect of $\mathrm{CR}$ on ROI. CR probability value $0.0000<\alpha 10 \%$ indicates that $\mathrm{CR}$ variables significantly affect the ROI. Coefficient value of 0.049 shows increase in CR by $1 \%$, and this will increase ROI by $0.049 \%$ with an assumption of ceteris paribus. This result is supported by Raheman et al (2010) revealing that the current ratio has a positive effect on the company profitability.

Current Ratio (CR) is one of liquidity ratios i.e. ratio aiming to measure the ability of a company in fulfilling its short term liability. The higher the CR of a company means the less risk of failure to meet the company's short-term liabilities. As a result, the risk that will be borne by shareholders also becomes smaller (Ang, 1997).
By the company's ability to meet its short-term liabilities on time or before due, the company gains profit by getting discounts on the short-term debt costs. Nevertheless, the results of a study conducted by Ray (2012) find that the current ratio has a negative effect on profitability. The negative relationship shows that a high current ratio involving greater current assets than current liabilities will reduce profitability, as the company may not have maximized its assets.

The third hypothesis was to examine the effect of FDR on ROI. FDR probability value of $0.0000<\alpha \quad 10 \%$ indicates that $\mathrm{CR}$ variable significantly affects the ROI. Coefficient value of -0.193 highlights that an increase of FDR by $1 \%$ will decrease ROI by $0.193 \%$ with an assumption of ceteris paribus. This result is supported by Raheman et al. (2010) revealing a negative relationship between debt ratio and profitability.

Margaretha and Nina (2008) revealed that financial debt has a positive effect on profitability. Similarly, this study also identifies that more debt will eventually reduce profitability. In brief, most of the palm oil plantations in this study have significant liabilities or debts.

The fourth hypothesis was to test the effect of FFAR on ROI. FFAR probability value of $0.0884<\alpha 10 \%$ indicates that FFAR variable significantly affects ROI. Coefficient value of 0.090 indicates that an increase in FFAR of $1 \%$ will increase ROI of $0.090 \%$ with an assumption of ceteris paribus. This notion is supported by the results of research conducted by Lazaridis and Tryfonidis (2006) arguing that fixed financial assets have a positive effect on profitability. According to Ray (2012), an increase in fixed asset components in the total assets of the company will increase profitability. Fixed assets intended on plantation companies consist of producing plantation crops, immature plantation crops, fixed assets, and other assets. Fixed asset installations, in forms of machinery and equipment, will significantly 
support the operations of the company especially during the harvest season. Rifai (2009) states that fixed assets, in forms of tools and production machines, have no significant effect on profitability, as there are other company policies that can affect profitability; e.g. additional hours to increase production.

In reference to the analysis estimation of the effect of working capital on profitability, the value of determination coefficient or R-squared is $78 \%$ i.e. the variability that can be explained by the variables in this study is $78 \%$, and the rest of $22 \%$ is influenced by other variables outside the model.

\section{Managerial Implication}

This study indicates that the working capital policy of $\mathrm{CCC}, \mathrm{CR}, \mathrm{FDR}$, and FFAR working capital variables can be utilized by company management and investors to improve the performance and observe the company liquidity and profitability. Of the four working capital variables, FDR significantly affects the profitability and has a negative coefficient i.e. an increase in total debt in the company can reduce profitability.

Financial management of the company should pay attention to the FDR value and accelerate its turnover in order to increase higher profitability. The results of regression analysis prove that in palm oil plantation companies, there is an influence of CCC on profitability, stable or decreasing $\mathrm{CCC}$ is a good sign for the company. On contrary, rising CCC ratio is not necessarily considered to be bad, yet it should attract analysts/investors to examine further the causes of the rising figure of CCC.

The results of this study exemplify that to evaluate the effectiveness of oil palm plantation companies in managing their working capital is by using the approach to minimize working capital in a condition that it should be sufficient to finance the company's operations. Minimizing working capital can be achieved by accelerating the collection of sales receivables, improving inventory turnover and reducing cash expenditures. The results of the panel regression model can also provide empirical evidence revealing that working capital policy has a significant effect on the company profitability. Therefore, working capital needs to be managed properly by company management in order to achieve maximum profit.

\section{CONCLUSIONS AND RECOMMENDATIONS}

\section{Conclusions}

Most of the plantation companies in IDX apply conservative working capital policy. This is indicated by looking at the positive net working capital and the average value of CCC in which the value is positive and the source of funding is mostly from equity to fund all of its fixed assets and some of its current assets. Companies adopting conservative policies have higher profits than those adopting aggressive approach composed of funding mostly sourced from short-term loans. This may be due to the risk factors faced by domestic plantation companies in general, which can be classified into micro and macro risk factors.

The results of panel regression analysis on the model in the study showed that the independent variables consisting of CCC, CR, FDR, and FFAR have a significant effect on ROI. The more efficient the working capital management is, as measured by Cash Conversion Cycle (CCC), the higher the company's profitability is, as measured by return on investment (ROI).

\section{Recommendations}

In reference to the number of variables affecting the profitability and working capital management, this study can be a reference to conduct further research related to other working capital measurements. In addition, it is also suggested to obtain the financial statements of companies that have not been consolidated, so that the sales data (credit and cash), Payable Account and Receivable Account of respective business unit as well as other related accounts in each company can be investigated more thoroughly.

\section{REFERENCES}

Afza T, Nazir MS. 2008. Working capital approaches and firms' returns in Pakistan. Pakistan Journal of Commerce and Social Sciences 1(1): 25-36.

Ang R. 1997. Buku Pintar Pasar Modal Indonesia. Jakarta: Penerbit Media Staff Indonesia.

Brigham E, Joel FH. 2011. Dasar-Dasar Manajemen Keuangan. Jilid ke-2. Ed ke-10. Jakarta: Penerbit Salemba Empat. 
P-ISSN: 2407-5434 E-ISSN: 2407-7321

Accredited by Ministry of RTHE Number 32a/E/KPT/2017

Chowdhury A, Amin MM. 2007. Working capital management practices in pharmaceutical companies listed in Dhaka Stock Exchange. BRAC University Journal 4(2): 75-86.

Jain NK. 2004. Working Capital Management. New Delhi: Ashish Publicing House.

Lazaridis I, Tryfonidis D. 2006. Relationship between working capital management and profitability of companies listed in the Athens Stock Exchange. Financial Management and Analysis 19(1): 2635.

Margaretha F, Nina A. 2008. Pengaruh working capital, fixed financial asset, financial debt, dan firm size terhadap profitabilitas. Jurnal Informasi, Perpajakan, Akuntansi dan Keuangan Publik. 3(1):29-43.

Mukhopadhyay D. 2004. Working capital management in heavy engineering firms-a case study. http:// www.myicwai.com/knowledgebank/fm48.[23 Feb 2015].

Nazir MS, Afza T. 2009. Working capital requirements and the determining factors in Pakistan. The IUP Journal of Applied Finance 15(4): 28-39.

Raheman A, Afza T, Qayyum A. 2011. Sector-wise performance of working capital management measures and profitability using ratio analysis. Interdisciplinary Journal of Contemporary
Research in Business 3(8): 285-303.

Raheman A, Afza T, Qayyum A, Bodla MA. 2010. Working capital management and corporate performance of manufacturing sector in Pakistan. International Research Journal of Finance and Economics (47): 151-163.

Ray S. 2012. Evaluating the impact of working capital management components on corporate profitability: evidence from Indian manufacturing firms. International Journal of Economic Practices and Theories 2(3):127-136.

Rifai N. 2009. Analisis financial distress dan kebutuhan modal kerja PT. Liza Herbal International [tesis]. Bogor: Institut Pertanian Bogor.

Valentina AH. 2014. Analisis manajemen modal kerja dan dampaknya terhadap profitabilitas dan nilai perusahaan (studi kasus pada industri logam di BEI) [tesis]. Bogor: Institut Pertanian Bogor.

Wang YJ. 2002. Liquidity management, operating performance, and corporate value: evidence from Japan and Taiwan. Journal of Multinational Financial Management 12: 159-169. https://doi. org/10.1016/S1042-444X(01)00047-0.

Yuliati NW. 2013. Pengaruh kebijakan modal kerja terhadap profitabilitas pada perusahaan hotel dan restoran di Bursa Efek Indonesia [tesis]. Bali: Universitas Udayana. 